\title{
Influence of environmental factors in the adherence of an atypical enteropathogenic Escherichia coli strain to epithelial cells
}

\author{
Fabiano T Romão ${ }^{1}$, Rodrigo T Hernandes ${ }^{1,2}$, Denise Yamamoto ${ }^{1}$, Lika Osugui ${ }^{1}$, Ana Flavia Popi ${ }^{1}$ \\ and Tânia A T Gomes ${ }^{1 *}$
}

\begin{abstract}
Background: Attachment is essential to maintain bacteria at their preferential intestinal colonization sites. There is little information on the influence of different environmental conditions in the interaction of atypical enteropathogenic Escherichia coli (aEPEC) strains with epithelial cells. In this study, we evaluated the effect of different glucose (5 and $25 \mathrm{mM})$ and $\mathrm{CO}_{2}(0.03$ and $5 \%)$ concentrations and presence of bile salts on the adhesiveness of the aEPEC strain 1551-2.

Results: We found that a $\mathrm{CO}_{2}$-enriched atmosphere enhanced the adhesiveness of the aEPEC 1551-2 strain independently of glucose concentrations or presence of bile salts. Conversely, the presence of high glucose concentration altered the original localized adherence (LA) pattern observed at $5 \mathrm{mM}$ glucose, which is characterized by the formation of compact bacterial clusters, to a hybrid adherence pattern (LA and an aggregative adherence-like pattern). In addition, at high glucose concentration, there was increased expression of the fimA gene, which encodes the major subunit of type 1 pilus (T1P), and an isogenic fimA mutant displayed only LA. The presence of bile salts did not interfere with the adhesion properties of the 1551-2 strain to HeLa cells.
\end{abstract}

Conclusions: Our data suggest that a $\mathrm{CO}_{2}$-enriched atmosphere could favor aEPEC adhesion to the host cells, whereas enhanced T1P production under high glucose concentration could allow bacteria to access more extensive intestinal colonization sites in the host at the beginning of the infectious process.

Keywords: Atypical EPEC, Glucose, type I pilus, Adherence, Environmental factors, Diarrhea

\section{Background}

Enteropathogenic Escherichia coli (EPEC) is an important cause of gastroenteritis in humans [1]. The EPEC pathotype is subdivided into typical EPEC (tEPEC) and atypical EPEC (aEPEC), where the main difference between the two subgroups is the presence of the large virulence EAF (EPEC adherence factor) plasmid (pEAF) in tEPEC and its absence in aEPEC $[2,3]$. pEAF encodes bundle-forming pilus (BFP), a type IV fimbria, which mediates a localized adherence (LA) pattern in vitro, and is characterized by the formation of compact microcolonies on the surface of HeLa/HEp-2 cells [4,5].

\footnotetext{
* Correspondence: tatg.amaral@unifesp.br

'Departamento de Microbiologia, Imunologia e Parasitologia, Universidade Federal de São Paulo (UNIFESP), Escola Paulista de Medicina, São Paulo, SP, Brazil

Full list of author information is available at the end of the article
}

The hallmark of EPEC pathogenesis is a histopathologic lesion termed attaching and effacing (AE) lesion, which is characterized by intimate bacterial adherence to enterocytes and effacement of microvilli [6]. The $\mathrm{AE}$ lesion is a consequence of the interaction between the outer membrane protein intimin and its receptor Tir (translocated intimin receptor), which is translocated through a type 3 secretion system (T3SS) into eukaryotic cells $[7,8]$. The genes involved in the AE lesion phenotype are localized in the pathogenicity island termed locus of enterocyte effacement or LEE region [9].

Attachment comprises a critical stage to avoid displacement of bacteria from its preferential site in the gut by the continuous flow of intestinal contents. The initial step in attachment of different diarrheagenic E. coli (DEC) pathotypes to the host intestinal epithelium is usually mediated 
by fimbrial and afimbrial adhesins [10,11]. Previous studies have demonstrated that environmental conditions may regulate the expression of DEC virulenceencoding genes including adhesins and T3SS-dependent effectors [12-15]. In a tEPEC strain, serotype O111: $\mathrm{H}^{-}$, Puente and coworkers found that BFP expression was increased at higher glucose concentrations, suggesting that $\mathrm{tEPEC}$ preferentially colonizes the proximal small intestine, where the glucose concentration is greater than $25 \mathrm{mM}$ [16]. This hypothesis was further confirmed in experiments employing an in vitro organ culture (IVOC) adhesion assay with intestinal tissues obtained from children [17].

Several studies in the literature have focused on identifying new putative adhesive structures, and the adherence pattern resulting from the interaction between these bacterial structures and host cells. However, particularly in aEPEC, very few studies have tried to understand how the intestinal environment may favor or prevent this interaction.

We previously identified an aEPEC strain, 1551-2 (serotype $\mathrm{ONT}: \mathrm{H}^{-}$), which displays the LA pattern in HeLa cells in the absence of BFP [18]. In the present study we evaluated the adherence pattern and colonization efficiency of aEPEC 1551-2 in HeLa cells cultivated at different $\mathrm{CO}_{2}$ and glucose concentrations and in the presence of bile salts.

\section{Results}

aEPEC 1551-2 strain adheres more efficiently to HeLa cells in an atmosphere supplemented with $\mathrm{CO}_{2}$

Quantitative assays demonstrated that the different glucose concentrations tested ( 5 and $25 \mathrm{mM}$ ) did not promote substantial alterations in the adhesiveness of aEPEC 1551-2 $(P>0.5)$, as observed in Figure 1A. However, air atmosphere with $5 \% \mathrm{CO}_{2}$ favored bacterialcell interaction, since the number of associated bacteria increased 2.3-fold at $5 \mathrm{mM}$ glucose and 1.7-fold at $25 \mathrm{mM}$ glucose, when compared with results obtained in assays performed in a normal air atmosphere (approximately $\left.0.03 \% \mathrm{CO}_{2}\right)(P<0.05)$.

To exclude the possibility of differences in bacterial growth rate in the different environmental conditions tested, a growth curve (measuring the $\mathrm{OD}_{600}$ ) was determined. Bacterial growth rates were not affected by the different conditions tested (data not shown), indicating that the difference observed in the quantitative adherence assays was due to the modification of the air atmosphere by the elevation of $\mathrm{CO}_{2}$ concentration to $5 \%$.

\section{High glucose concentration modifies the adherence} pattern of 1551-2 strain to HeLa cells

Regarding the aEPEC 1551-2 adherence pattern, the LA originally identified by Vieira and coworkers [18] was only detected in the presence of low glucose, independently of the $\mathrm{CO}_{2}$ concentration used (Figure $1 \mathrm{~B}$ and $\mathrm{D}$ ). On the other hand, at high glucose concentration, we identified a hybrid adherence pattern, in which LA was observed concurrently with an aggregative adherencelike (AA-like) pattern on the HeLa cell and on the glass slide surface (abiotic surface) (Figure 1C and E).

\section{The AA-like pattern of 1551-2 strain is dependent on} type 1 pilus (T1P) production at high glucose concentration Since T1P is so far the only adhesin, besides intimin, identified in the 1551-2 strain [18-20], we hypothesized that the AA-like pattern would depend on T1P production. To investigate the contribution of T1P in the establishment of the AA-like pattern, we first evaluated the relative expression of the fim $\mathrm{A}$ gene (encodes for monomer that forms fimbriae) at two glucose concentrations (5 and $25 \mathrm{mM}$ ). By comparing the experiments performed in medium supplemented with different glucose concentrations, it was possible to observe an increase in fimA gene expression (1.75-fold and 2.03fold, after 3 and $6 \mathrm{~h}$ of incubation, respectively) in experiments performed in medium with high glucose (Figure 2A).

Furthermore, we employed an isogenic fimA mutant (1551-2 $\triangle$ fimA) to test the adherence pattern of this strain at high glucose. These experiments demonstrated that in contrast with the wild type aEPEC 1551-2 (Figure 2B), the 1551-2 $\triangle$ fimA strain displayed only the LA pattern, while the AA-like pattern was completely abolished (Figure 2C). These findings clearly point to an association between glucose concentration and T1P production, since the isogenic mutant no longer produced the AA-like pattern, even in the presence of high glucose concentration (Figure 2C). Complementation of the fimA mutant with the pFimA recombinant plasmid restored its ability to produce the LA/AA-like pattern in the presence of high glucose (Figure 2E). The 1551-2 $\Delta$ fimA strain carrying empty pBADMyc-His A vector (Table 1 ) produced LA on HeLa cells but was unable to produce the AA-like pattern (Figure 2D), confirming that L-arabinose did not affect the adherence phenotype of the complemented strain.

\section{Presence of bile salts does not interfere with the} adhesion properties of 1551-2 strain with HeLa cells

The presence of bile salts caused no significant alterations in the adhesive properties of aEPEC 1551-2 to epithelial cells (data not shown). Under all conditions tested, the adherence pattern and the amount of bacteria associated with HeLa cells were not significantly different, indicating that bile salts did not influence bacterial colonization. 

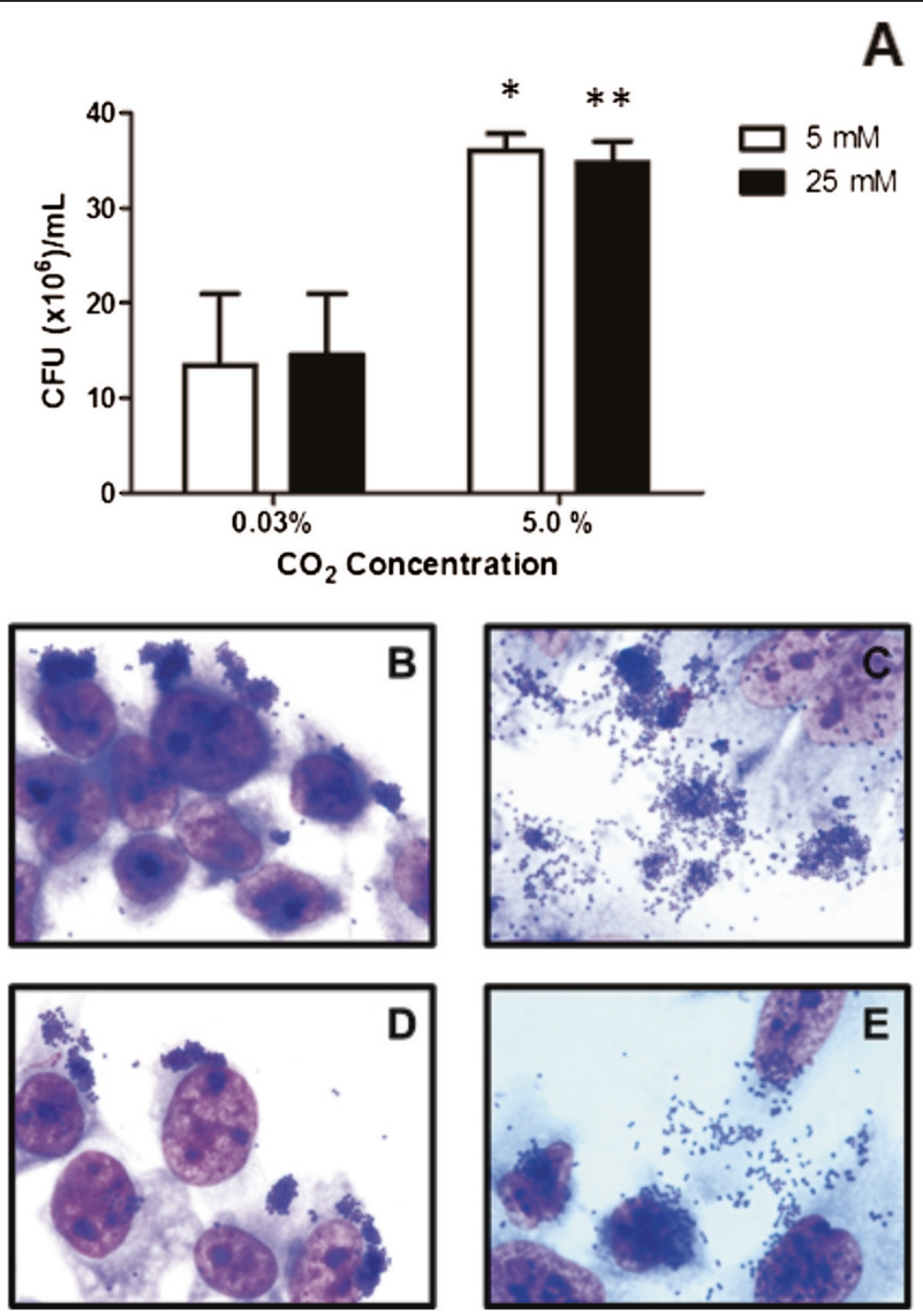

Figure 1 Comparison of quantitative and qualitative adherence of aEPEC 1551-2 strain to HeLa cells under different environmental conditions. (A) Number of adherent bacteria recovered after $6 \mathrm{~h}$ of incubation with HeLa cells, demonstrating the positive influence of $\mathrm{CO}_{2}(5 \%)$ in the adhesiveness of aEPEC 1551-2. (B, C, D and E) Distinct adherence patterns observed in 1551-2 interaction with HeLa cells, after incubation in medium containing $5 \mathrm{mM}$ ( $\mathbf{B}$ and $\mathbf{D}$ ) or $25 \mathrm{mM}$ ( $\mathbf{C}$ and $\mathbf{E}$ ) glucose, in a normal air atmosphere ( $\mathbf{B}$ and $\mathbf{C}$ ) and in an atmosphere of $5 \% \mathrm{CO}_{2}$ ( $\mathbf{D}$ and $\mathbf{E}$ ). The hybrid LA/AA-like pattern is observed over and around cells, only in assays performed in medium containing $25 \mathrm{mM}$ glucose ( $\mathbf{C}$ and $\mathbf{E}){ }^{*}$ and ** represent statistical differences observed between experiments performed under $0.03 \%$ and $5 \% \mathrm{CO}_{2}$ concentration, in medium containing low $(P=0.03)$ or high $(P=0.002)$ glucose concentration, respectively.

\section{Discussion}

In this study, we analyzed some environmental factors that could influence the colonization process of aEPEC 1551-2 strain in the intestinal environment, by mimicking characteristics (such as the gas atmosphere and glucose concentration) commonly found in different parts of the intestines.

We observed that the efficiency of bacterial association rose approximately two fold in a $5 \% \mathrm{CO}_{2}$ atmosphere, independently of the glucose concentration employed (Figure 1A). According to described by Babb (1977), hydrogen, nitrogen and $\mathrm{CO}_{2}$ are the three prevailing gases present in the intestine, with $\mathrm{CO}_{2}$ concentrations varying between 5.1 and 29\% [21]. Due to experimental limitations, only $0.03 \%$ and $5 \% \mathrm{CO}_{2}$ were tested.

Haigh and co-workers showed improved protein secretion by the tEPEC E2348/69 strain in the presence of 5\% $\mathrm{CO}_{2}$, independently of the presence of eukaryotic cells [22]. However, Kenny and coworkers questioned the actual influence of high $\mathrm{CO}_{2}$ concentrations in improving bacterial protein secretion, since, in the adherence assays performed in a $5 \% \mathrm{CO}_{2}$ atmosphere, sodium bicarbonate is added to the culture medium to buffer the acidic $\mathrm{pH}$ induced by the higher $\mathrm{CO}_{2}$ concentration [8]. Therefore, 


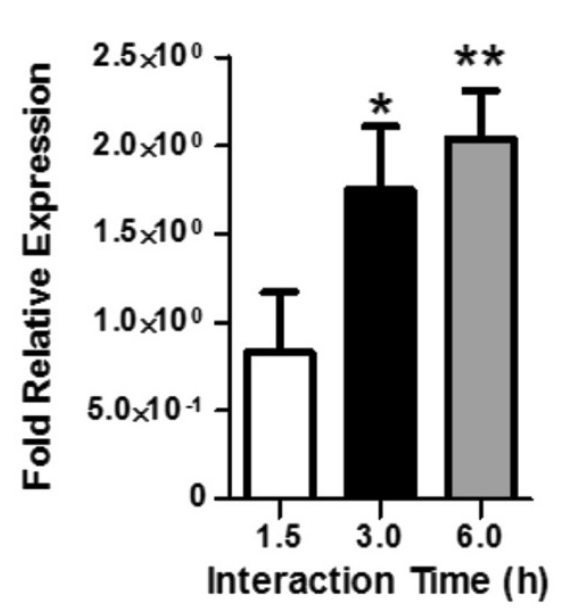

A
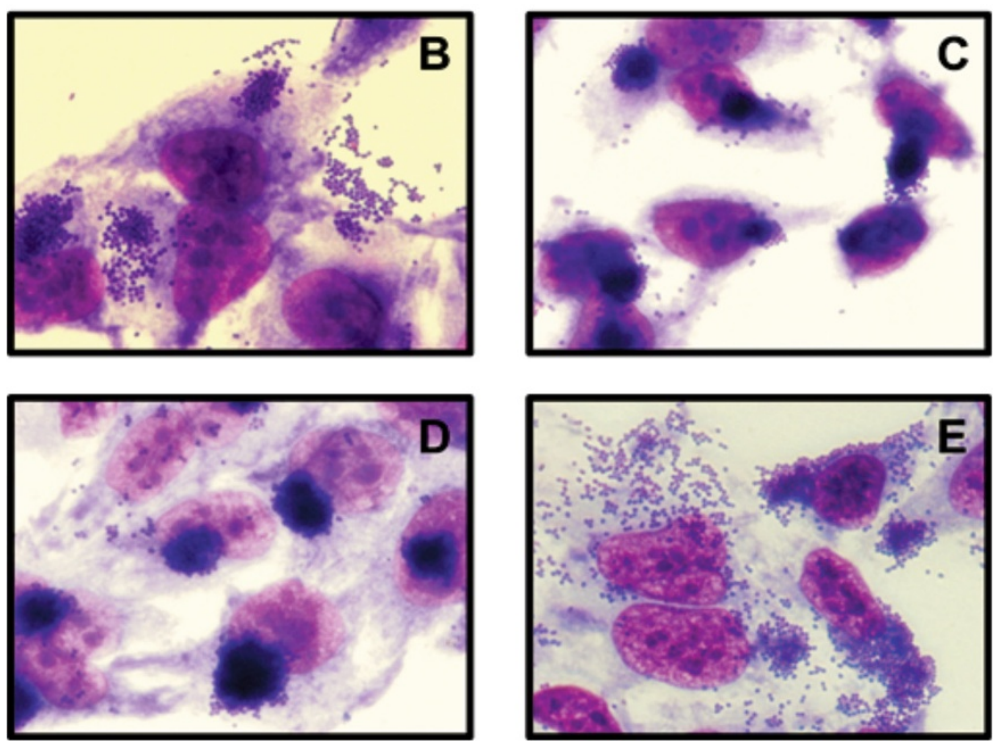

Figure 2 The aggregative adherence-like pattern shown by aEPEC 1551-2 at high glucose concentration is dependent on type 1 pili production. (A) Relative expression of fimA in presence of $5 \mathrm{mM}$ (calibrator) and $25 \mathrm{mM}$ glucose at $1.5 \mathrm{~h}, 3 \mathrm{~h}$ and $6 \mathrm{~h}$. The data showed that at 3 and $6 \mathrm{~h}$, there was an increase in fimA expression of $75 \pm 21 \%$ and $103 \pm 15 \%$, respectively. (B, C, D and E) Adherence patterns observed with

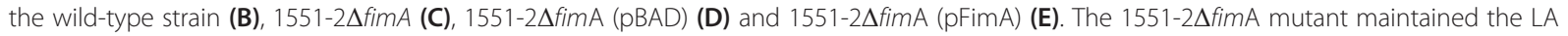
pattern on HeLa cells, but the AA-like pattern was no longer observed, pointing to the involvement of T1P in the establishment of this phenotype. * and ** indicate statistical differences observed between experiments performed at 5 and $25 \mathrm{mM}$ glucose after $3 \mathrm{~h}(P=0.02)$ and $6 \mathrm{~h}(P=0.002)$ of incubation, respectively.

the higher protein concentrations observed in such situations could be due to the presence of sodium bicarbonate instead of $\mathrm{CO}_{2}$. Since $\mathrm{CO}_{2}$ (or sodium bicarbonate) stimulate EPEC protein secretion, we believe that the increased adhesiveness of aEPEC 1551-2 in the atmosphere supplemented with $5 \% \mathrm{CO}_{2}$ could be related to increased secretion of the EPEC secreted proteins that form the T3SS-translocon (EspA, B and D), in view of the fact that this structure interacts with epithelial cells [23]. In addition, in our previous studies, the T3SS-translocon was shown to mediate aEPEC 1551-2 adherence to
HeLa cells in the absence of intimin [24]. Of note, intimin mediates the intimate bacterial attachment observed in the formation of AE lesions [1].

During the flow through the small intestine, glucose is rapidly absorbed, reaching a concentration higher than $25 \mathrm{mM}$ in the duodenum, dropping to less than $5 \mathrm{mM}$ in the ileum, until it is undetectable in the jejunum, depending on the host's diet [12]. Quantitative experiments to evaluate the efficiency of bacterial interaction with HeLa cells showed no statistical difference between the numbers of associated bacteria when assays were 
Table 1 Bacterial strains and plasmids used in this study

\begin{tabular}{|c|c|c|}
\hline E. coli strains and plasmids & Characteristics & Reference \\
\hline \multicolumn{3}{|l|}{ Strains } \\
\hline $1551-2$ & aEPEC $\left(\mathrm{ONT}: \mathrm{H}^{-}\right)$isolated from a diarrheic child, which expresses $\mathrm{LA}$ on HeLa cells $\left(\mathrm{Nal} \mathrm{R}^{\mathrm{R}}\right.$ ) & [18] \\
\hline 1551-2 $\Delta$ fimA & 1551-2 fimA::zeo $\left(\mathrm{Nal}^{\mathrm{R}} \mathrm{Zeo}{ }^{\mathrm{R}}\right)$, T1P mutant & [24] \\
\hline $1551-2 \Delta f i m A(p B A D)$ & 1551-2 mutant harboring pBAD/Myc-His A vector $\left(\mathrm{Nal}^{\mathrm{R}} \mathrm{Zeo}^{\mathrm{R}} \mathrm{Amp}^{\mathrm{R}}\right)$ & [24] \\
\hline $1551-2 \Delta$ fimA(pFimA) & 1551-2 mutant harboring pFimA $\left(\mathrm{Nal}^{R} \mathrm{Zeo}^{\mathrm{R}} \mathrm{Amp}^{\mathrm{R}}\right)$ & [24] \\
\hline \multicolumn{3}{|l|}{ Plasmid } \\
\hline $\mathrm{pBAD} / \mathrm{Myc}-\mathrm{His} \mathrm{A}$ & $\begin{array}{l}\text { Cloning vector, harboring the araBAD promoter ( } \mathrm{PBAD} \text { ) from E. coli, which is induced } \\
\text { in the presence of } L \text {-arabinose. }\end{array}$ & Invitrogen \\
\hline pFimA & pBAD/Myc-His A vector harboring the fimA gene from aEPEC 1551-2 & [24] \\
\hline
\end{tabular}

$\mathrm{Nal}^{\mathrm{R}}$ : nalidixic acid resistant; Zeo ${ }^{\mathrm{R}}$ : zeocin resistant; $\mathrm{Amp}^{\mathrm{R}}$ : ampicillin resistant; LA: Localized adherence.

performed in the presence of 5 or $25 \mathrm{mM}$ glucose at the same $\mathrm{CO}_{2}$ concentration (Figure $1 \mathrm{~A}$ ).

However, regardless of the $\mathrm{CO}_{2}$ concentration used, two distinct adherence patterns were detected depending on the glucose concentration present in the culture medium. At $5 \mathrm{mM}$ glucose, bacteria adhered in the LA pattern, originally reported by Vieira and coworkers [18], whereas at $25 \mathrm{mM}$ glucose, a hybrid pattern consisting of LA and AA-like patterns was seen. Previous studies by our laboratory found that in contact with HeLa cells the 1551-2 strain produces T1P [20]. In addition, this strain lacks adhesin-encoding genes that are commonly found in other diarrheagenic E. coli pathotypes and extraintestinal pathogenic E. coli (ExPEC), as shown in previous studies [18-20,25].

In the present study, we showed that fimA expression increased 1.75-fold and 2.03-fold, in the period between 3 and $6 \mathrm{~h}$, when $25 \mathrm{mM}$ glucose was used as compared to $5 \mathrm{mM}$ glucose. Various studies in the literature have shown that glucose influences the expression of fimbrial and non-fimbrial adhesins. Our results are in accordance with previous studies showing that adhesins such as the bundle-forming pilus (of tEPEC), colonization factor antigens (of enterotoxigenic E. coli) and toxin-coregulated pilus (of Vibrio cholera) are positively regulated by high glucose concentrations [16,26,27]. Müller and coworkers reported that two uropathogenic E. coli strains responded in opposite ways regarding fimbriation in the presence of cAMP receptor protein (CRP) and 3',5'-cyclic adenosine monophosphate (cAMP) complex by phase variation of fimA promoter [28]. CRP-cAMP is a signaling protein complex formed when there is a reduction in glucose concentration in the environment [28]. Therefore, the CRP-cAMP complex can induce the fimA promoter in the absence of glucose. However, in the presence of glucose and absence of CRP-cAMP, a complex of Lrp (leucine-responsive protein), DNA gyrase and FimB (an invertase of the T1P operon) raise the amount of fimbriated bacteria in the population by maintaining the phase variation of fimA promoter in the $\mathrm{ON}$ position, reflecting a glucose-dependent event [28]. In our study, we found that the AA-like pattern of the 1551-2 strain depended on the presence of a high glucose concentration, leading us to hypothesize that the increased fimA expression in the later incubation periods corresponded to a glucose-dependent phenotype.

In contrast to the wild-type strain, the isogenic fim $A$ mutant lost the ability to produce the AA-like pattern, even when the assay was performed in medium supplemented with high glucose concentration, confirming the influence of this sugar in the establishment of the AA-like pattern. The involvement of T1P in the AA pattern was first described in enteroaggregative E. coli (EAEC) prototype strain 042 , by mutating the fimD gene (encoding the T1P usher). The fimD mutant strain was approximately $80 \%$ less adherent to HEp-2 cells than the wild-type strain [29]. Additionally, T1P has been implicated in biofilm formation in both EAEC (042) and aEPEC (1551-2) strains, reinforcing the involvement of this adhesin in the pathogenesis of diarrheagenic E. coli strains [24,29].

As suggested by Edwards and Puente, a combination of environmental signals may provide an intestinal map to identify an appropriate niche for bacterial colonization [12]. The differences in the adherence patterns on HeLa cells under some diverse environmental conditions could reflect the differential expression of adhesinencoding genes in the distinct parts of the intestine. In view of the evidence that under high glucose concentration the modification in the adherence pattern from LA to LA/AA-like was not associated with an increase of the number of associated bacteria, we can hypothesize that T1P production can negatively interfere with microcolony formation in experiments performed in this circumstance. Therefore, the higher level of T1P production in $25 \mathrm{mM}$ glucose could suggest that these fimbriae are involved in the first steps of the association of aEPEC1551-2 with the proximal small intestine, where the highest glucose concentration is detected [30]. 


\section{Conclusions}

Altogether, our data suggest that a $\mathrm{CO}_{2}$-enriched atmosphere could favor aEPEC adhesion to the host cells, whereas enhanced T1P production under high glucose concentration could allow bacteria to access more extensive intestinal colonization sites in the host at the beginning of the infectious process.

\section{Methods}

\section{Bacterial strain}

The aEPEC 1551-2 strain (serotype ONT: $\mathrm{H}^{-}$) was isolated as part of standard patient care from a diarrheic child (23 months old), in the absence of other recognized pathogens, during an epidemiological study of diarrhea carried out at the Universidade Federal de São Paulo (UNIFESP), Brazil. This strain was initially reported to produce LA (in the 6-h assay) in HeLa cells [18]. The fimA mutant and complemented strains were obtained in a subsequent study from our laboratory [24]. The most relevant characteristics of the bacterial strains and plasmids employed in the present study are described in Table 1.

Bacterial strains were routinely grown aerobically in Luria-Bertani (LB) medium or Dulbecco's modified Eagle's medium (DMEM, Gibco, USA) at $37^{\circ} \mathrm{C}$. When appropriate, strains were cultured in the presence of nalidixic acid $(20 \mu \mathrm{g} / \mathrm{ml})$ and/or zeocin $(60 \mu \mathrm{g} / \mathrm{ml})$. Assays employing the complemented strain were performed in the presence of $0.01 \%$ L-arabinose as previously described [24].

\section{HeLa cells culture}

HeLa cells were cultivated in DMEM supplemented with $10 \%$ fetal bovine serum (Gibco, USA) and in the presence of $1 \%$ antibiotic mixture (penicillin and streptomycin, Life Technologies, USA) in an atmosphere of $5 \%$ $\mathrm{CO}_{2}$ at $37^{\circ} \mathrm{C}$. To determine the adherence pattern and quantify the total number of associated bacteria (quantitative assay), HeLa cells were seeded in 24-well microplates, containing glass coverslips and the same media. Adherence assays were performed using semiconfluent cells (approximately 70\% confluence) after two days of incubation.

\section{Qualitative assays (adherence pattern)}

Qualitative assays were performed as described earlier [20]. Briefly, HeLa cells were washed with phosphate buffered saline (PBS, pH 7.4). After washing, $1.0 \mathrm{ml}$ of fresh medium (DMEM supplemented with $2 \%$ fetal bovine serum) was added to the cell monolayers, and the HeLa cells were then inoculated with suspensions (approximately $10^{8} \mathrm{CFU} / \mathrm{mL}$ ) of bacteria grown in LB broth (overnight culture) diluted 1:50, and incubated at $37^{\circ} \mathrm{C}$. During the interaction, we evaluated the effects of glucose concentration ( 5 or $25 \mathrm{mM}$ ), presence of bile salts (absence or presence of $0.015 \% \mathrm{w} / \mathrm{v}$ ) and
$\mathrm{CO}_{2}$ concentration $(0.03$ or $5 \%$, with DMEM supplemented with 0.35 or $35 \mathrm{mM}$ sodium bicarbonate, respectively). After $6 \mathrm{~h}$ of interaction (with a washing step after $3 \mathrm{~h}$ ), the preparation was washed six times with PBS and then fixed with methanol (Merck, Germany) for $1 \mathrm{~h}$, stained with May Grünwald-Giemsa stain, and examined by light microscopy for adherence pattern determination.

\section{Quantitative assays}

For determination of the total number of associated bacteria, HeLa cells were inoculated and the experiment was conducted as described above. During the interaction, we evaluated the same assay conditions as in the qualitative assays. After $6 \mathrm{~h}$ of interaction (with a washing step after $3 \mathrm{~h}$ ), the preparations were washed six times with PBS. Next, the cells were lysed with $1 \%$ Triton X-100, and serial dilutions were plated on MacConkey agar plates. After approximately $18 \mathrm{~h}$ of incubation at $37^{\circ} \mathrm{C}$, the resulting colonies were counted for determination of the total number of associated bacteria. All assays were performed in biological and technical triplicate, and the results represented the means \pm standard errors.

\section{Quantitative PCR assay}

aEPEC 1551-2 was grown for $18 \mathrm{~h}$ in LB broth (or broth supplemented with antibiotics) and incubated statically at $37^{\circ} \mathrm{C}$. The pre-inoculum was diluted 1:50 in DMEM supplemented with 5 or $25 \mathrm{mM}$ glucose, and incubated statically for $1.5,3.0$ or $6.0 \mathrm{~h}$, at $37^{\circ} \mathrm{C}$, in an atmosphere of $0.03 \% \mathrm{CO}_{2}$. After incubation, the preparation was centrifuged at 5,900 g for $3 \mathrm{~min}$, and the pellet was treated with Trizol (Invitrogen, USA) for total RNA extraction. cDNA was synthesized using SuperScript III First-Strand (Invitrogen, USA). The primers used for detection of fimA expression were: (forward) $5^{\prime}-\mathrm{TC}$ GATGCGGGATCTGTTGA-3' and (reverse) 5'-ACC GACGGCAGAGCTGGT-3'. All data were normalized to the expression levels of rpoA (RNA polymerase subunit A), by using the following primers: (forward) 5 ' -G CGCTCATCTTCTTCCGAAT-3' and (reverse) 5' -CG CGGTCGTGGTTATGTG-3', and analyzed with the comparative threshold $\left(\mathrm{C}_{\mathrm{T}}\right)$ method. The expression levels of fimA at different glucose concentrations were compared by using the relative quantification method. Realtime data were expressed as fold change of the expression levels of fimA at different glucose concentrations. Data obtained with $25 \mathrm{mM}$ glucose were compared by using the relative quantification method, using strains incubated with $5 \mathrm{mM}$ glucose as the calibrator for each time point. Total RNAs of all treatments were obtained from three independent assays. Statistical differences were determined by the Student $t$-test, and $P \leq 0.05$ was considered statistically significant. 


\section{Competing interests}

The authors declare that they have no competing interests.

\section{Authors' contributions}

FTR performed all experiments in this study and drafted the manuscript. DY $L O$, and AFP analyzed the results and formatted the data. RTH and TATG designed the experimental procedures, supervised all the experimental works, and corrected and produced the final version of the manuscript. All authors read and approved the final manuscript.

\section{Acknowledgments}

This study was supported by grants from Fundação de Amparo à Pesquisa do Estado de São Paulo (FAPESP 11/12664-5) and Conselho Nacional de Desenvolvimento Científico e Tecnológico (CNPq, grants:304453/2011-0 and 480664/2012-9). FTR and DY received fellowships from Coordenação de Aperfeiçoamento de Pessoal de Nível Superior (CAPES). Dr. A. Leyva helped with English editing of the manuscript.

\section{Author details}

${ }^{1}$ Departamento de Microbiologia, Imunologia e Parasitologia, Universidade Federal de São Paulo (UNIFESP), Escola Paulista de Medicina, São Paulo, SP, Brazil. ²Departamento de Microbiologia e Imunologia, Instituto de Biociências, Universidade Estadual Paulista (UNESP), Botucatu, SP, Brazil.

Received: 15 July 2014 Accepted: 18 November 2014

Published online: 20 December 2014

\section{References}

1. Kaper JB, Nataro JP, Mobley HL: Pathogenic Escherichia coli. Nat Rev Microbiol 2004, 2:123-140.

2. Kaper JB: Defining EPEC. Rev Microbiol 1996, 27:130-133.

3. Trabulsi LR, Keller R, Gomes TA: Typical and atypical enteropathogenic Escherichia coli. Emerg Infect Dis 2002, 8:508-513.

4. Girón JA, Ho AS, Schoolnik GK: An inducible bundle-forming pilus of enteropathogenic Escherichia coli. Science 1991, 254:710-713.

5. Donnenberg MS, Girón JA, Nataro JP, Kaper JB: A plasmid-encoded type IV fimbrial gene of enteropathogenic Escherichia coli associated with localized adherence. Mol Microbiol 1992, 6:3427-3437.

6. Moon HW, Whipp SC, Argenzio RA, Levine MM, Giannella RA: Attaching and effacing activities of rabbit and human enteropathogenic Escherichia coli in pig and rabbit intestines. Infect Immun 1983, 41:1340-1351.

7. Jerse $A E, Y u J$, Tall BD, Kaper JB: A genetic locus of enteropathogenic Escherichia coli necessary for the production of attaching and effacing lesions on tissue culture cells. Proc Natl Acad Sci U S A 1990, 87:7839-7843.

8. Kenny B, DeVinney R, Stein M, Reinscheid DJ, Frey EA, Finlay BB: Enteropathogenic $E$. coli (EPEC) transfers its receptor for intimate adherence into mammalian cells. Cell 1997, 91:511-520.

9. McDaniel TK, Jarvis KG, Donnenberg MS, Kaper JB: A genetic locus of enterocyte effacement conserved among diverse enterobacterial pathogens. Proc Natl Acad Sci U S A 1995, 92:1664-1668.

10. Torres AG, Zhou X, Kaper JB: Adherence of diarrheagenic Escherichia coli strains to epithelial cells. Infect Immun 2005, 73:18-29.

11. Arenas-Hernandez MMP, Martínez-Laguna Y, Torres AG: Clinical Implication of Enteroadherent Escherichia coli. Curr Gastroenterol 2012. [http://dx.doi. org/10.1007/s1 1894-012-0277-1]

12. Edwards RA, Puente JL: Fimbrial expression in enteric bacteria: a critical step in intestinal pathogenesis. Trends Microbiol 1998, 6:282-287.

13. Beinke C, Laarmann S, Wachter C, Karch H, Greune L, Schmidt MA: Diffusely adhering Escherichia coli strains induce attaching and effacing phenotypes and secrete homologs of Esp proteins. Infect Immun 1998, 66:528-539.

14. Torres AG, Milflores-Flores L, Garcia-Gallegos JG, Patel SD, Best A, La Ragione RM, Martinez-Laguna Y, Woodward MJ: Environmental regulation and colonization attributes of the long polar fimbriae (LPF) of Escherichia coli 0157:H7. Int J Med Microbiol 2007, 297:177-185.

15. Torres AG, Tutt CB, Duval L, Popov V, Nasr AB, Michalski J, Scaletsky IC: Bile salts induce expression of the afimbrial LDA adhesin of atypical enteropathogenic Escherichia coli. Cell Microbiol 2007, 9:1039-1049.
16. Puente JL, Bieber D, Ramer SW, Murray W, Schoolnik GK: The bundle-forming pili of enteropathogenic Escherichia coli: transcriptional regulation by environmental signals. Mol Microbiol 1996, 20:87-100.

17. Phillips $A D$, Frankel $G$ : Intimin-mediated tissue specificity in enteropathogenic Escherichia coli interaction with human intestinal organ cultures. J Infect Dis 2000, 181:1496-1500.

18. Vieira MA, Andrade JR, Trabulsi LR, Rosa AC, Dias AM, Ramos SR, Frankel G, Gomes TA: Phenotypic and genotypic characteristics of Escherichia coli strains of non-enteropathogenic E. coli (EPEC) serogroups that carry eae and lack the EPEC adherence factor and Shiga toxin DNA probe sequences. J Infect Dis 2001, 183:762-772.

19. Gomes TA, Hernandes RT, Torres AG, Salvador FA, Guth BE, Vaz TM, Irino K, Silva RM, Vieira MA: Adhesin-encoding genes from Shiga toxin-producing Escherichia coli are more prevalent in atypical than in typical enteropathogenic E. coli. J Clin Microbiol 2011, 49:3334-3337.

20. Hernandes RT, Velsko I, Sampaio SC, Elias WP, Robins-Browne RM, Gomes TA, Girón JA: Fimbrial adhesins produced by atypical enteropathogenic Escherichia coli strains. Appl Environ Microbiol 2011, 77:8391-8399.

21. Babb RR: Intestinal gas (Medical Information). West J Med 1977, 127:362-363.

22. Haigh $\mathrm{R}$, Baldwin T, Knutton S, Williams PH: Carbon dioxide regulated secretion of the EaeB protein of enteropathogenic Escherichia coli. FEMS Microbiol Lett 1995, 129:63-67.

23. Cleary J, Lai LC, Shaw RK, Straatman-Iwanowska A, Donnenberg MS, Frankel G, Knutton S: Enteropathogenic Escherichia coli (EPEC) adhesion to intestinal epithelial cells: role of bundle-forming pili (BFP), EspA filaments and intimin. Microbiology 2004, 150:527-538.

24. Hernandes RT, De la Cruz MA, Yamamoto D, Girón JA, Gomes TA: Dissection of the role of pili and type 2 and 3 secretion systems in adherence and biofilm formation of an atypical enteropathogenic Escherichia coli strain. Infect Immun 2013, 81:3793-3802.

25. Gomes TA, Irino K, Girão DM, Girão VB, Guth BE, Vaz TM, Moreira FC, Chinarelli SH, Vieira MA: Emerging enteropathogenic Escherichia coli strains? Emerg Infect Dis 2004, 10:1851-1855.

26. Gaastra W, Syennerholm AM: Colonization factors of enterotoxigenic Escherichia coli isolated from children in north India. J Infect Dis 1996, 174:768-776.

27. Skorupski K, Taylor RK: Cyclic AMP and its receptor protein negatively regulate the coordinate expression of cholera toxin and toxin-coregulated pilus in Vibrio cholerae. Proc Natl Acad Sci U S A 1997, 94:265-270.

28. Müller CM, Aberg A, Straseviçiene J, Emody L, Uhlin BE, Balsalobre C: Type 1 fimbriae, a colonization factor of uropathogenic Escherichia coli, are controlled by the metabolic sensor CRP-cAMP. PLOS Pathog 2009. [http://dx.doi.org/10.1371/journal.ppat.1000303]

29. Moreira CG, Carneiro SM, Nataro JP, Trabulsi LR, Elias WP: Role of type I fimbriae in the aggregative adhesion pattern of enteroaggregative Escherichia coli. FEMS Microbiol Lett 2003, 226:79-85.

30. Ferraris RP, Yasharpour S, Lloyd KC, Mirzayan R, Diamond JM: Luminal glucose concentrations in the gut under normal conditions. Am J Physiol 1990, 259:G822-G837.

\section{Submit your next manuscript to BioMed Central and take full advantage of:}

- Convenient online submission

- Thorough peer review

- No space constraints or color figure charges

- Immediate publication on acceptance

- Inclusion in PubMed, CAS, Scopus and Google Scholar

- Research which is freely available for redistribution 